\section{Quality of diet related to food insecurity and food stamps use among older people}

\author{
Maria F. Montoya, Andre W. Hite, \\ Patricia Rohrbeck, Binky Bawa, \\ Oladayo O. Akinwolemiwa, \\ Alicia M. Benson, Mary Luna-Hollen, \\ Carlos A. Reyes-Ortiz \\ Department of Social \& Behavioral \\ Sciences, School of Public Health, \\ University of North Texas Health Science \\ Center, Forth Worth, TX, USA
}

\begin{abstract}
We explore the association between quality of diet and food security status among older persons. Cross-sectional survey of large national samples, from the National Health \& Nutrition Examination Surveys (1988-1994 \& 2001-2002), in the United States. A total of 5,039 and 2,040 men and women aged 60 and older, respectively. The dependent variable was the healthy eating index (HEI; 2000 and 2005) as a measure of diet quality. The independent variable of interest was food security status and was categorized as food secure, food insecurity receiving food stamps and food insecurity not receiving food stamps. In multivariate analyses, food insecure individuals not receiving food stamps had lower total HEI-2000 scores compared to food secure individuals $(\beta=-3.91, \mathrm{SE}=1.81, \mathrm{P}=0.0310)$. Factors independently associated with high HEI (2000 or 2005) scores were female gender, being married, highly educated or wealthy, with very good/ excellent perceived health, or without functional limitations. Food secure individuals had better quality of diet than food insecure individuals. Among food insecure individuals, receiving food stamps was not associated with diet quality. Food insecure families with older individuals may need new methods of dissemination of food and nutrition programs - methods that yield positive and promising changes in the health status of this special population group.
\end{abstract}

\section{Introduction}

The network on poverty reduction and propoor economic policies of the development assistance committee of the Organization for Economic Cooperation and Development (OECD) are addressing food security economics globally. ${ }^{1}$ In late 2008 , when the severity of economic crisis became evident, some OECD countries implemented special measures to ease the financial stress in the sector, including credit preferences, and additional direct support. For example, the U.S. Congress approved the 2008 Farm Bill (Food, Conservation and Energy Act of 2008), that included food assistance and agricultural development, food stamps, and domestic food distribution, among others. ${ }^{1}$ According to the World Food Summit, food security includes three equally important inter-related components: food availability, access and utilization. ${ }^{2}$ By contrast, food insecurity is a frequent and threatening problem, especially among older populations in the US and globally. ${ }^{2}$ Between $2 \%$ and $10 \%$ of the older people have been considered as experiencing food insecurity; these percentages may increase among older persons with low socioeconomic status, disabled or those living alone. ${ }^{3-6}$ For example, the U.S. Department of Agriculture reported that $8.1 \%$ of households with older persons and $8.8 \%$ of older persons living alone had food insecurity in 2008. 6 Social and economic factors also affect their nutritional status through insufficient food or limited food choice. 5 These factors include poverty and economic stress due to lack of income and assets, as well as to competing demands for money, such as medication, health care, transportation, and housing costs. ${ }^{5}$

The quality of the diet in older people could be affected by food insecurity due to limited access to a variety of foods or to the capacity to purchase food.5,7 For example, older persons with food insecurity may have lower macronutrient (e.g., proteins) and micronutrient (e.g., vitamin B-12, niacin, zinc) intakes compared to older persons without food insecurity. ${ }^{3-5,7}$ Food insecurity has been shown to be associated with a variety of unfavorable health outcomes, including anemia, malnutrition, obesity, anxiety, depression, and suicide..$^{3-5,7,8}$

Food assistance programs have been and continue to be designed to prevent food insecurity, particularly among older persons.9,10 Federal food and nutrition assistance programs include the largest national program under the U.S. Department of Health and Human Services, the U.S. Administration on Aging, The Older Americans Act (OAA) Nutrition Program. The OAA Titles I-VII aim to reduce hunger and food insecurity and promote socialization of elders through the delivery of supportive home and community-based Services. ${ }^{11}$ These include the food stamp program (today known as the Supplemental Nutrition Assistance Program = SNAP, in the United States), congregate meals and homedelivered meals. ${ }^{12-14}$ Eligible older persons able to receive food stamps include those with low household income or resources and residents of federally subsidized housing in the US. ${ }^{15,16}$ The dollar amount of food stamps received has
Correspondence: Carlos A. Reyes-Ortiz, Department of Social \& Behavioral Sciences, School of Public Health, University of North Texas Science Center, 3500 Camp Bowie Boulevard (EAD-711B), Forth Worth, TX 76107-2699, USA

Tel. +1.817.735.5136 - Fax: +1.817.735.0255.

E-mail: carlos.reyesortiz@unthsc.edu

Key words: food insecurity, food stamps, older people, diet quality, healthy eating index.

Contributions: CR0, manuscript writing supervision, statistical supervision, data analysis; all authors participate in the content, concept and design, literature review, interpretation of data, preparation/edition and approval of the final manuscript.

Conflict of interest: the authors report no conflicts of interest.

Received for publication: 27 August 2010.

Revision received: 11 April 2011.

Accepted for publication: 11 April 2011.

This work is licensed under a Creative Commons Attribution 3.0 License (by-nc 3.0)

CC Copyright M.F. Montoya et al., 2011

Licensee PAGEPress, Italy

Ageing Research 2011; 3:e3

doi:10.4081/ar.2011.e3

been associated with weight change particularly in persons with persistent food insecurity. 17 Older adult SNAP participants living alone on average receive US $\$ 65$ per month and US $\$ 152$ per month if they live with others.18 In older persons, food stamp use has been associated with predisposing characteristics (female gender, younger age, minority ethnic group), enabling characteristics (not speaking English well, low education, 1 or more children at home, receiving welfare), and need characteristics (home owners with a mortgage, vision/ hearing difficulties, functional limitations). ${ }^{15}$

However, it is unknown whether receiving foods stamps may improve quality of diet among food insecure older persons. There is a recent concern for the quality of diet among those adult persons receiving food stamps. Indeed, receiving foods stamps has been linked to the food insecurity-obesity relationship, ${ }^{19}$ or even having an independent effect from food insecurity on obesity among adult or older adult persons.20 In 1999-2000, for Americans at or over 65 years of age, $68.8 \%$ were overweight, and $29.8 \%$ were obese. While Medicare cost projections are $34 \%$ higher for obese versus non-obese older adults, obesity affects disability but not life expectancy. ${ }^{21}$ The relationship between body mass index (BMI) and mortality forms a U-shaped graphic distribution among older adults, with the greatest risk for poor functional outcomes at the lowest 
and highest BMI.11 The USDA Economic Research Service defines food insecurity as a measure of the full range of food insecurity as experienced by households. ${ }^{8}$ Increasingly more low income working adults are caring for elders at home. Obesity remains highest among the most disadvantaged groups. ${ }^{22}$ An explanation for the greater prevalence of obesity in low-income households is the frequent consumption of less-expensive and unhealthy food (typically energy-dense, nutrient-poor food). The potential explanations for linking poverty, food insecurity, and the obesity paradox include low income household eating patterns, low household purchasing power, and poor diet quality linked to low cost foods. ${ }^{23}$

Previous studies have shown that economic context, including food assistance programs along with income and medication coverage, influences healthful eating among homebound older adults experiencing food insufficiency. ${ }^{24}$ In this study, based in previous models on food insufficiency or food stamp use, $2,15,24$ we used a conceptual model (Figure 1) to categorize fundamental (geographic, demographic, socioeconomic, and health-related) and proximate (food security status) factors that may influence quality of diet among older participants. ${ }^{24}$ Our objective was to explore the relationship between quality of diet, assessed by the healthy eating index, and food insecurity with or without food stamps use among older persons.

\section{Materials and Methods}

\section{Data source}

The National Health \& Nutrition Examination Surveys (NHANES), large US surveys conducted from 1988 to 1994 (NHANES III), and from 2001 to 2002, are major sources of information on the nutritional and health status of the US population. 25 Weights indicating the probability of being sampled were assigned to each respondent, enabling results to represent the US population for each ethnic group. Data were collected via standardized questionnaires administered by health professionals at participants' homes. Data were also obtained via standardized medical examinations by physicians, medical technicians, and other health professionals at the NHANES mobile examination centers (MEC). Interviews were conducted in English and Spanish after informed consents were obtained at the initial home interview. The interviewer gave each person selected for the survey a brochure, approved by the Institutional Review Board, which described the survey procedures. Response rates were $78 \%$ for both the home interview and the med- ical examination. 25

\section{Study sample}

The samples for our secondary data analyses included 5,039 (1988-1994), and 2,040 (20012002) men and women aged 60 years and older who completed the home questionnaire. From the original data $(6,596$ and 2,390 ; respectively), participants with missing healthy eating index (HEI) were excluded (1,557 for HEI-2000 and 350 for HEI-2005). Compared to participants who remained in the analyses, participants who were excluded were more likely to be female, unmarried, older ( $\geq 75$ ), low educated, poor, living alone, with poor self-rated health, not obese, and disabled.

\section{Measurements outcome}

The outcome variable was the quality of diet measured by the Healthy Eating Index (HEI). ${ }^{26,27}$ To calculate the HEI-2000, Food Guide Pyramid serving sizes recommended by the US Department of Agriculture were applied to the food servings obtained through a 24hour dietary recall survey in NHANES III (1988-1994 data); these data were released in 2000.26 The HEI-2000 total score ranges from 0 (worst)-100 (best), where a higher overall HEI-2000 score usually indicates better diet quality. The HEI-2000 components are total fruits, total vegetables, total grains, milk (dairy products), meat (and beans), sodium, total fat, saturated fat, cholesterol, and variety. The HEI2000 has been used as a measure of quality of diet among diverse populations. ${ }^{26,27}$ The HEI2005 , based on 2001-2002 NHANES data, 28 differs from the HEI-2000 in assessing the quality of the diet on a density basis (e.g., amounts per 1,000 calories of intake) and introducing new components for oils, for calories from
Solid Fat, Alcohol, and Added Sugar (SoFAAS), and three subgroups of foods - whole fruit, dark green and orange vegetables and legumes and whole grains. ${ }^{29}$ The HEI-2005 has been validated in older populations. ${ }^{30}$ The healthy eating index (2000 or 2005) was normally distributed and was used as a continuous variable $(0-100)$ and as a categorical variable, according to previous studies, 31 as follows: good $(\geq 81)$, needs improvement (51-80) and poor ( $\leq 50)$. The primary independent variable for both NHANES III and NHANES 2001-2002 was food security status and was categorized as: 1food secure individual, 2- food insecure individual receiving food stamps, and 3 - food insecure individual not receiving food stamps.

In NHANES III (1988-1994), food insecurity was evaluated as one question: Do you have: enough food to eat, sometimes not enough food to eat, or often not enough to eat? An individual choosing enough food to eat was considered as food secure individual. While an individual choosing sometimes not enough food to eat or often not enough to eat was considered as food insecure individual. Among those food insecure individuals, foods stamps use were evaluated as: Did you receive food stamps in any of the past 12 months? Yes / no.

In NHANES 2001-2002, food insecurity was evaluated by a household 18 items scale (or 10 items in households without children) based on the Current Population Survey Food Security Supplement, 32 and the four categories created were: food secure $(n=2,144 ; 89.7 \%)$, marginally food secure (at risk in the guide) ( $n=101 ; 4.2 \%)$, food insecure without hunger $(\mathrm{n}=99 ; 4.2 \%)$, and food insecure with hunger (moderate and severe hunger have been combined into one category) $(n=46 ; 1.9 \%)$. In our analyses, we considered the first category as a food secure individual and any of the other

\section{Fundamental factors \\ Proximate factors \\ Outcome}

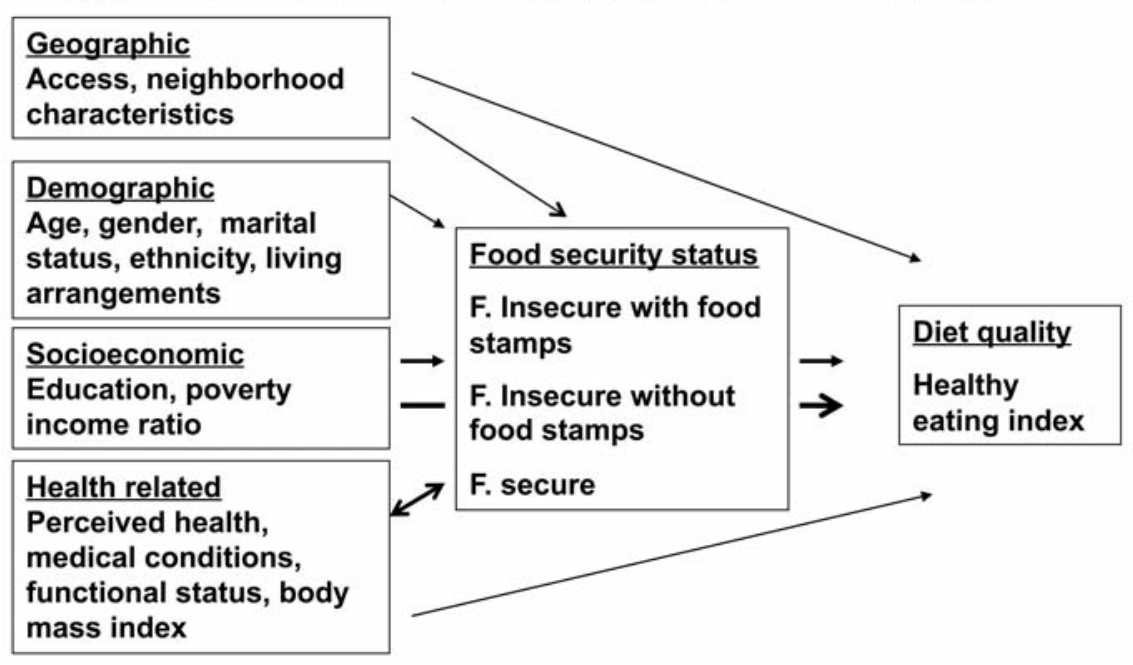

Figure 1. Influence of food security status and other factors on quality of diet. 
three categories as a food insecure individual. Among those food insecure individuals, foods stamps use was evaluated as: Did you receive food stamps in any of the past 12 months? Yes/No.

Other variables in both NHANES III (19881994) and 2001-2002 were age, gender, marital status, education, income/poverty ratio (a higher number indicates a high income), ethnicity, self-perception of health (poor/fair vs. good/very good/excellent), functional status and medical conditions. Similarly to previous research on NHANES, 4 functional status included two instrumental activities of daily living (IADL; preparing meals and managing money) and four activities of daily living (ADL; eating, dressing, getting in or out of bed and transferring) and were used as categorical variables, dichotomized as $0 v s \geq 1$ limitations. Medical conditions included the self-report of arthritis, stroke, COPD (emphysema or chronic bronchitis), cancer, diabetes mellitus, hypertension, or cardiac disease. A summative score of medical conditions was constructed from 0 to 7 , and was dichotomized as 0-1 $v s \geq 2$. Preliminary analysis showed that similar results were obtained when we used medical conditions variable as either categorical or continuous.

\section{Statistical analysis}

All statistical analyses were carried out using version 9.1 of SAS for Windows (SAS Institute, Cary, North Carolina). All analyses incorporated sampling weights that adjusted for unequal probabilities of selection (SAS SURVEY procedures). To describe the study populations, we used descriptive statistics (weighted percentages and means), and performed bivariate statistical testing using the ttest/ANOVA and the Chi-square (Tables 1, 2). To test the bivariate association between HEI2000 or HEI-2005 and food security status categories we used ANOVA and the $\chi^{2}$ (Table 3 ). With a continuous dependent variable (total HEI-2000 or 2005), we used multivariate linear regression analyses to examine the independent association of HEI with food security status categories (Table 4). With a categorical dependent variable (good versus needs improvement/poor; HEI-2000 or 2005), we used multivariate logistic regression analyses to examine the independent association of HEI with food security status categories (Table 4).

\section{Results}

Food insecurity prevalence among older participants was $3.6 \%$ in years $1988-94$ (3.3\% for those living alone) and $10.4 \%$ in years 2001 2002 (9.8\% for those living alone). Table 1 shows the means of HEI-2000 score and pro- portions of individuals within the HEI-2000 categories, according to sociodemographic characteristics, NHANES 1988-1994. A good HEI-2000 score was associated with younger age (60-74), female gender, being married, non-Black ethnic group, living with others, high education, less poor, very good/excellent perceived health, low number of medical conditions, and low number of functional limitations (ADL or IADL).
Table 2 shows the means of HEI-2005 score and proportions of individuals within the HEI2005 categories, according to sociodemographic characteristics, NHANES 2001-2002. A good HEI-2005 score was associated with high education, very good/excellent perceived health, low number of medical conditions, and low number of functional limitations (ADL or IADL).

Table 3 shows the means of HEI scores and

Table 1. Means of HEI-2000 score and proportions of individuals within the HEI-2000 category, according to sociodemographic characteristics, NHANES 1988-1994.

\begin{tabular}{|c|c|c|c|c|c|}
\hline Sar & mple size & Mean \pm SE & Good & Needs improvement & Poor \\
\hline $\begin{array}{l}\text { Age (years) } \\
\quad 60-74 \\
\geq 75 \\
\text { P-value }\end{array}$ & $\begin{array}{l}3227 \\
1812\end{array}$ & $\begin{array}{c}68.05 \pm 0.31 \\
68.57 \pm 0.41 \\
0.28\end{array}$ & $\begin{array}{c}17.5 \\
15.0 \\
<0.0001\end{array}$ & $\begin{array}{l}54.6 \\
45.7\end{array}$ & $\begin{array}{l}27.9 \\
39.4\end{array}$ \\
\hline $\begin{array}{l}\text { Gender } \\
\text { Male } \\
\text { Female } \\
\text { P-value }\end{array}$ & $\begin{array}{l}2451 \\
2588\end{array}$ & $\begin{array}{c}66.18 \pm 0.45 \\
69.79 \pm 0.32 \\
<0.0001\end{array}$ & $\begin{array}{c}14.8 \\
18.2 \\
0.0224\end{array}$ & $\begin{array}{l}53.9 \\
50.5\end{array}$ & $\begin{array}{l}31.3 \\
31.3\end{array}$ \\
\hline $\begin{array}{l}\text { Marital status } \\
\text { Married } \\
\text { Unmarried } \\
\text { P-value }\end{array}$ & $\begin{array}{l}2956 \\
2083\end{array}$ & $\begin{array}{c}68.36 \pm 0.36 \\
67.89 \pm 0.39 \\
0.39\end{array}$ & $\begin{array}{c}18.4 \\
14.4 \\
<0.0001\end{array}$ & $\begin{array}{l}55.5 \\
47.1\end{array}$ & $\begin{array}{l}26.1 \\
38.5\end{array}$ \\
\hline $\begin{array}{l}\text { Ethnic group } \\
\text { Whites } \\
\text { Blacks } \\
\text { Hispanics } \\
\text { Other } \\
\text { P-value }\end{array}$ & $\begin{array}{l}2915 \\
1010 \\
968 \\
146\end{array}$ & $\begin{array}{c}68.74 \pm 0.32 \\
62.22 \pm 0.38 \\
65.28 \pm 0.61 \\
70.47 \pm 0.83 \\
<0.0001\end{array}$ & $\begin{array}{c}17.2 \\
9.5 \\
13.2 \\
23.5 \\
<0.0001\end{array}$ & $\begin{array}{l}52.0 \\
49.9 \\
57.7 \\
54.0\end{array}$ & $\begin{array}{l}30.8 \\
40.6 \\
29.1 \\
22.5\end{array}$ \\
\hline $\begin{array}{l}\text { Living arrangements } \\
\text { With others } \\
\text { Alone } \\
\text { P-value }\end{array}$ & $\begin{array}{l}3741 \\
1298\end{array}$ & $\begin{array}{c}68.09 \pm 0.30 \\
68.46 \pm 0.45 \\
0.49\end{array}$ & $\begin{aligned} & 17.2 \\
& 15.5 \\
&<0.0001\end{aligned}$ & $\begin{array}{l}54.7 \\
45.2\end{array}$ & $\begin{array}{l}28.1 \\
39.3\end{array}$ \\
\hline $\begin{array}{l}\text { Education (years) } \\
\quad<12 \\
\geq 12 \\
\text { P-value }\end{array}$ & $\begin{array}{l}2840 \\
2199\end{array}$ & $\begin{array}{c}65.23 \pm 0.39 \\
70.21 \pm 0.34 \\
<0.0001\end{array}$ & $\begin{aligned} & 11.3 \\
& 20.9 \\
< & 0.0001\end{aligned}$ & $\begin{array}{l}49.8 \\
53.7\end{array}$ & $\begin{array}{l}38.9 \\
25.4\end{array}$ \\
\hline $\begin{array}{l}\text { Poverty Income ratio } \\
<1.00 \text { (below poverty level } \\
\geq 1.00 \\
\text { P-value }\end{array}$ & $\begin{array}{r}\text { l) } 1509 \\
3530\end{array}$ & $\begin{array}{l}65.72 \pm 0.60 \\
68.77 \pm 0.29 \\
<0.0001\end{array}$ & $\begin{aligned} & 12.3 \\
& 18.0 \\
< & 0.0001\end{aligned}$ & $\begin{array}{l}44.5 \\
54.2\end{array}$ & $\begin{array}{l}43.2 \\
27.8\end{array}$ \\
\hline $\begin{array}{l}\text { Self-perceived health } \\
\text { Excellent/very good/good } \\
\text { Fair/poor } \\
\text { P-value }\end{array}$ & $\begin{array}{l}3231 \\
1808\end{array}$ & $\begin{array}{c}69.04 \pm 0.35 \\
65.99 \pm 0.43 \\
<0.0001\end{array}$ & $\begin{array}{l}19.0 \\
11.5 \\
<0.0001\end{array}$ & $\begin{array}{l}53.0 \\
49.7\end{array}$ & $\begin{array}{l}28.0 \\
38.8\end{array}$ \\
\hline $\begin{array}{l}\text { Medical conditions } \\
0-1 \\
\geq 2 \\
\text { P-value }\end{array}$ & $\begin{array}{l}2830 \\
2209\end{array}$ & $\begin{array}{c}68.18 \pm 0.36 \\
68.19 \pm 0.40 \\
0.98\end{array}$ & $\begin{array}{c}17.8 \\
15.3 \\
0.0293\end{array}$ & $\begin{array}{l}52.2 \\
51.8\end{array}$ & $\begin{array}{l}30.0 \\
32.9\end{array}$ \\
\hline $\begin{array}{l}\text { ADL limitations } \\
\quad 0 \\
\geq 1 \\
\text { P-value }\end{array}$ & $\begin{array}{l}3978 \\
1061\end{array}$ & $\begin{array}{c}68.71 \pm 0.30 \\
65.71 \pm 0.65 \\
0.0001\end{array}$ & $\begin{array}{c}18.2 \\
11.1 \\
<0.0001\end{array}$ & $\begin{array}{l}53.2 \\
47.2\end{array}$ & $\begin{array}{l}28.6 \\
41.7\end{array}$ \\
\hline $\begin{array}{l}\text { IADL limitations } \\
\quad 0 \\
\geq 1 \\
\text { P-value }\end{array}$ & $\begin{array}{c}4391 \\
648\end{array}$ & $\begin{array}{c}68.46 \pm 0.28 \\
65.54 \pm 0.65 \\
0.0002\end{array}$ & $\begin{array}{c}17.7 \\
9.6 \\
<0.0001\end{array}$ & $\begin{array}{l}53.5 \\
41.1\end{array}$ & $\begin{array}{l}28.8 \\
49.3\end{array}$ \\
\hline $\begin{array}{l}\text { Body mass index }\left(\mathrm{Kg} / \mathrm{m}^{2}\right) \\
\quad<30 \\
\geq 30 \\
\text { P-value }\end{array}$ & $\begin{array}{l}3836 \\
1203\end{array}$ & $\begin{array}{c}68.49 \pm 0.29 \\
67.20 \pm 0.60 \\
0.05\end{array}$ & $\begin{array}{c}16.9 \\
16.7 \\
<0.0001\end{array}$ & $\begin{array}{l}61.5 \\
49.6\end{array}$ & $\begin{array}{l}21.6 \\
33.7\end{array}$ \\
\hline
\end{tabular}

P-values testing based on weight data: Wald $\mathrm{F}$ test for means, $\chi^{2}$ for HEI categories. 
proportions of individuals within the HEI categories, according to food security status, NHANES 1988-1994 (HEI-2000) and 2001-2002 (HEI-2005). Food secure individuals had significant higher HEI total scores compared to food insecure ones (HEI-2000, $\mathrm{P}<0.0001$; HEI$2005, \mathrm{P}=0.0002$ ). Also, food secure individuals had higher proportions of the good HEI category or lower proportions for poor categories compared to food insecure ones (HEI-2000, $\mathrm{P}=0.0240$; HEI-2005, $\mathrm{P}=0.0243$ ).

Table 4 shows the multivariate analyses for the HEI as a function of food security status. When predicting the total HEI-2000 scores, food insecure individuals no receiving food stamps had lower total HEI-2000 scores compared to food secure individuals $(\beta=-3.91$, $\mathrm{SE}=1.81, \mathrm{P}=0.0310$ ). Other significant independent predictors for high total HEI-2000 scores were older age (75+), female gender, being married, highly educated or not-poor, with very good/ excellent perceived health, and without ADL limitations. Significant factors for a good (versus needs improvement/ poor) HEI2000 were female gender, being highly educated and with very good/ excellent perceived health. Significant independent predictors for a high HEI-2005 score were female gender, living with others, being highly educated, without IADL limitations, and being non-obese. Significant factors for a good (versus needs improvement/ poor) HEI-2005 were female gender, being married, highly educated or notpoor, and without IADL limitations.

\section{Discussion}

In this study we explored the relationship between quality of diet and food security status among older persons. We found that food secure individuals had better quality of diet than food insecure individuals. Among food insecure older individuals, receiving food stamps was not associated with diet quality.

In previous studies conducted by Lee and Frongillo in 2001,3,4 the authors examined the nutritional and health consequences associated with food insecurity of people aged 60 years and older in the United States, using also data from NHANES III (1988-1994) as we did in our analyses. Lee and Frongillo found that among the 6,596 older persons, only $3.3 \%$ were food insecure. 4 This proportion is very close to what we found in our analyses (3.6\%) for NHANES III using the same question to evaluate food insecurity, and suggesting that despite excluding participants with missing HEI, the proportion of food insecure individuals was not affected. Lee and Frongillo also found that food insecure older persons had lower nutrient intakes (e.g., protein, iron, zinc, vitamins B-6 and $\mathrm{B}-12$, riboflavin and niacin) than those that were food secure. 4 This was in agreement with our results using NHANES III where food insecure older persons had poor quality of diet, indicated by lower HEI scores.

Our proportion of food insecurity using the NHANES 2001-2002 was close to those of other US national databases. ${ }^{6}$ In contrast, the proportions of food insecurity are usually higher in other older populations. For example among Indiana community-dwelling older adults par-

Table 2. Means of HEI-2005 score and proportions of individuals within the HEI-2005 category, according to sociodemographic characteristics, NHANES 2001-2002.

\begin{tabular}{|c|c|c|c|c|c|}
\hline Sam & nple size & Mean \pm SE & Good & Needs improvement & Poor \\
\hline $\begin{array}{l}\text { Age (years) } \\
60-74 \\
\geq 75 \\
\text { P-value }\end{array}$ & $\begin{array}{c}1323 \\
717\end{array}$ & $\begin{array}{c}67.33 \pm 0.68 \\
66.88 \pm 0.92 \\
0.71\end{array}$ & $\begin{array}{l}16.8 \\
18.2 \\
0.23\end{array}$ & $\begin{array}{l}71.8 \\
66.4\end{array}$ & $\begin{array}{l}11.4 \\
15.4\end{array}$ \\
\hline $\begin{array}{l}\text { Gender } \\
\text { Male } \\
\text { Female } \\
\text { P-value }\end{array}$ & $\begin{array}{c}1063 \\
977\end{array}$ & $\begin{array}{c}65.82 \pm 0.66 \\
68.49 \pm 0.75 \\
0.0127\end{array}$ & $\begin{array}{l}15.0 \\
19.3 \\
0.05\end{array}$ & $\begin{array}{l}70.3 \\
70.2\end{array}$ & $\begin{array}{l}14.7 \\
10.5\end{array}$ \\
\hline $\begin{array}{l}\text { Marital status } \\
\text { Married } \\
\text { Unmarried } \\
\text { P -value }\end{array}$ & $\begin{array}{c}792 \\
1248\end{array}$ & $\begin{array}{c}67.14 \pm 0.69 \\
67.32 \pm 0.69 \\
0.85\end{array}$ & $\begin{array}{l}17.8 \\
16.2 \\
0.81\end{array}$ & $\begin{array}{l}69.7 \\
71.2\end{array}$ & $\begin{array}{l}12.5 \\
12.6\end{array}$ \\
\hline $\begin{array}{l}\text { Ethnic group } \\
\text { Whites } \\
\text { Blacks } \\
\text { Hispanics } \\
\text { Other } \\
\text { P-value }\end{array}$ & $\begin{array}{c}1345 \\
301 \\
349 \\
45\end{array}$ & $\begin{array}{c}67.56 \pm 0.65 \\
66.36 \pm 1.14 \\
66.79 \pm 0.71 \\
66.68 \pm 2.16 \\
0.11\end{array}$ & $\begin{array}{l}10.2 \\
11.4 \\
19.1 \\
17.9 \\
0.38\end{array}$ & $\begin{array}{l}73.2 \\
80.0 \\
69.5 \\
69.7\end{array}$ & $\begin{array}{c}16.6 \\
8.6 \\
11.4 \\
12.4\end{array}$ \\
\hline $\begin{array}{l}\text { Living arrangements } \\
\text { With others } \\
\text { Alone } \\
\text { P-value }\end{array}$ & $\begin{array}{c}1520 \\
520\end{array}$ & $\begin{array}{c}66.82 \pm 0.62 \\
68.30 \pm 0.88 \\
0.17\end{array}$ & $\begin{array}{l}16.9 \\
18.0 \\
0.67\end{array}$ & $\begin{array}{l}70.0 \\
70.9\end{array}$ & $\begin{array}{l}13.1 \\
11.1\end{array}$ \\
\hline $\begin{array}{l}\text { Education (years) } \\
\quad<12 \\
\geq 12 \\
\text { P-value }\end{array}$ & $\begin{array}{c}645 \\
1395\end{array}$ & $\begin{array}{c}62.72 \pm 1.11 \\
68.52 \pm 0.73 \\
0.0013\end{array}$ & $\begin{array}{c}9.3 \\
19.6 \\
0.0212\end{array}$ & $\begin{array}{l}72.5 \\
69.5\end{array}$ & $\begin{array}{l}18.2 \\
10.9\end{array}$ \\
\hline $\begin{array}{l}\text { Poverty Income ratio } \\
\quad<1.00 \text { (below poverty level) } \\
\geq 1.00 \\
\text { P-value }\end{array}$ & $\begin{array}{l}353 \\
1687\end{array}$ & $\begin{array}{c}66.24 \pm 1.03 \\
67.36 \pm 0.63 \\
0.41\end{array}$ & $\begin{array}{l}21.3 \\
16.5 \\
0.20\end{array}$ & $\begin{array}{l}63.2 \\
71.4\end{array}$ & $\begin{array}{l}15.5 \\
12.1\end{array}$ \\
\hline $\begin{array}{l}\text { Self-perceived health } \\
\text { Excellent/very good/good } \\
\text { Fair/poor } \\
\text { P-value }\end{array}$ & $\begin{array}{c}1543 \\
497\end{array}$ & $\begin{array}{c}67.81 \pm 0.57 \\
64.45 \pm 0.92 \\
0.0047\end{array}$ & $\begin{array}{c}18.0 \\
13.8 \\
0.0426\end{array}$ & $\begin{array}{l}70.6 \\
68.4\end{array}$ & $\begin{array}{l}11.4 \\
17.8\end{array}$ \\
\hline $\begin{array}{l}\text { Medical conditions } \\
\quad 0-1 \\
\geq 2 \\
\text { P-value }\end{array}$ & $\begin{array}{l}1004 \\
1036\end{array}$ & $\begin{array}{c}68.46 \pm 0.49 \\
65.94 \pm 0.68 \\
0.0010\end{array}$ & $\begin{array}{c}19.0 \\
15.4 \\
0.0425\end{array}$ & $\begin{array}{l}70.8 \\
69.7\end{array}$ & $\begin{array}{l}10.2 \\
14.9\end{array}$ \\
\hline $\begin{array}{l}\text { ADL limitations } \\
0 \\
\geq 1 \\
\text { P-value }\end{array}$ & $\begin{array}{c}1617 \\
423\end{array}$ & $\begin{array}{c}67.82 \pm 0.57 \\
64.47 \pm 1.05 \\
0.0107\end{array}$ & $\begin{array}{c}17.3 \\
16.9 \\
0.0099\end{array}$ & $\begin{array}{l}71.9 \\
62.7\end{array}$ & $\begin{array}{l}10.8 \\
20.4\end{array}$ \\
\hline $\begin{array}{l}\text { IADL limitations } \\
\quad 0 \\
\geq 1 \\
\text { P-value }\end{array}$ & $\begin{array}{l}1778 \\
262\end{array}$ & $\begin{array}{l}67.73 \pm 0.57 \\
62.62 \pm 0.82 \\
0.0002\end{array}$ & $\begin{array}{c}18.1 \\
9.1 \\
0.0022\end{array}$ & $\begin{array}{l}70.3 \\
70.1\end{array}$ & $\begin{array}{l}11.6 \\
20.8\end{array}$ \\
\hline $\begin{array}{l}\text { Body mass index }\left(\mathrm{Kg} / \mathrm{m}^{2}\right) \\
\quad<30 \\
\geq 30 \\
\text { P-value }\end{array}$ & $\begin{array}{l}1503 \\
537\end{array}$ & $\begin{array}{l}67.94 \pm 0.73 \\
65.18 \pm 1.11 \\
0.08\end{array}$ & $\begin{array}{l}18.5 \\
13.8 \\
0.59\end{array}$ & $\begin{array}{l}69.4 \\
72.4\end{array}$ & $\begin{array}{l}12.1 \\
13.8\end{array}$ \\
\hline
\end{tabular}

P-values testing based on weight data: Wald $\mathrm{F}$ test for means, $\chi^{2}$ for HEI categories. ticipating in home-delivered meals program, $25.2 \%$ were food insecure in 2006.13 Among community-dwelling older adults participating in congregate meals program, $19.6 \%$ were food insecure in 2006. ${ }^{14}$

Other studies reported that receiving food stamps has been associated with obesity. In one study, Webb et al..$^{20}$ found that food stamp program participation was associated with higher BMI among adults or older adults in 
Massachusetts. In another study, Leung and Villamor ${ }^{33}$ found that participation in food assistance programs among adults in California was associated with obesity independent of food insecurity and socioeconomic status. However, since food purchasing patterns are very complex in the context of economic crisis, food stamps, despite increasing the food purchasing power overall, may still be insufficient to allow users to meet optimal diet intakes; food purchasing patterns may remain the same because that money could be applied to other more pressing household needs (e.g., home utilities). ${ }^{20}$

A limitation of this study is the cross-sectional design of NHANES III, which prevented us from drawing causal inferences. A single 24-h dietary recall from a cross-sectional survey cannot provide detailed information on the extent and duration of inadequate nutrient intake among food-insecure persons. ${ }^{4}$ The HEI is based on a 24-hour recall that may not be representative of individual nutrient intakes because of day-to-day variation in food consumption. However, the HEI-2000 and the HEI2005 have been validated as measures for diet quality in United States populations. ${ }^{34,35}$ Another limitation is that we used two different measures for food security, al-item question in NHANES III and a 18-item scale in NHANES 2001-2002. Indeed, the 1-item question underestimated the prevalence of food insecurity. However, the 18 -item scale resulted in an estimation of food insecurity close to other US databases. The comparison of our food insecurity results with studies using different food insecurity scales (terminology used in the survey to describe food security and insecurity) could yield inaccurate results.

The NHANES 2001-2002 18-item food insecurity scale used in our analyses is a replication of the USDA scale that is also composed of 18 items which refer to children and adult food insecurity, and the final score is imputed by considering the presence or absence of children; it essentially measures qualitative and quantitative compromises in food intake with declining household resources. ${ }^{32}$ Other measures for food insecurity such as the Radimer instrument was initially comprised of 12 items; had slight modifications made to the instrument in subsequent applications to provide categorical determinations of household food insecurity and individual (adult) food insecurity. 36 The FANTA HFIAS 9-item scale is an adaptation of the USDA scale that has been used in several countries and appears to distinguish the food secure from the insecure households across different cultural contexts. ${ }^{37}$

In sum, food secure individuals had better quality of diet than food insecure individuals. Among food insecure individuals, receiving food stamps was not associated with diet qual-
Table 3. Means of HEI scores and proportions of individuals within the HEI categories, according to food security status, NHANES 1988-1994 (HEI-2000) and 2001-2002 (HEI2005).

$\begin{array}{cccc} & \text { HEI-2000 score } & \text { HEI-2000 categories (\%) } \\ \text { NHANES III (1988-1992) } & \text { Sample size } & \begin{array}{c}\text { Mean } \pm \text { SE } \\ \text { Good }\end{array} \text { Needs } & \text { Poor } \\ \text { improvement } & \end{array}$

\begin{tabular}{|c|c|c|c|c|c|}
\hline \multicolumn{6}{|c|}{ Food security status } \\
\hline $\begin{array}{l}\text { Food insecurity, } \\
\text { receiving food stamps }\end{array}$ & 72 & $61.16 \pm 1.95$ & 6.5 & 64.6 & 28.9 \\
\hline $\begin{array}{l}\text { Food insecurity, } \\
\text { no receiving food stamps }\end{array}$ & 107 & $60.83 \pm 1.40$ & 12.1 & 64.3 & 23.6 \\
\hline $\begin{array}{l}\text { Food secure, } \\
\text { no receiving food stamps }\end{array}$ & 4860 & $68.31 \pm 0.29$ & 21.7 & 66.7 & 11.6 \\
\hline P-value & & $<0.0001$ & 0.0240 & & \\
\hline NHANES 2001-2002 & Sample size & $\begin{array}{l}\text { HEI-2005 score } \\
\text { Mean } \pm \text { SE }\end{array}$ & $\begin{array}{l}\text { HE } \\
\text { Good }\end{array}$ & $\begin{array}{l}5 \text { cate } \\
\text { Needs } \\
\text { provem }\end{array}$ & $\begin{array}{l}(\%) \\
\text { Poor }\end{array}$ \\
\hline
\end{tabular}

Food security status

\begin{tabular}{lccccc}
$\begin{array}{l}\text { Food insecurity, } \\
\text { receiving food stamps }\end{array}$ & 32 & $62.52 \pm 3.07$ & 18.1 & 53.6 & 28.3 \\
\hline $\begin{array}{l}\text { Food insecurity, } \\
\text { no receiving food stamps }\end{array}$ & 180 & $62.74 \pm 1.53$ & 9.6 & 72.8 & 17.6 \\
$\begin{array}{l}\text { Food secure, } \\
\text { no receiving food stamps }\end{array}$ & 1828 & $67.51 \pm 0.61$ & 17.6 & 70.3 & 12.1 \\
\hline P-value & & 0.0002 & 0.0243 & & \\
\hline
\end{tabular}

P-values testing based on weight data: Wald $\mathrm{F}$ test for means, $\chi^{2}$ for HEI categories.

Table 4. Adjusted odds ratios for food status categories predicting HEI high score or good category, NHANES 1988-1994 (HEI-2000) and 2001-2002 (HEI-2005).

$\begin{array}{ccc} & \begin{array}{c}\text { Predicting HEI-2000 } \\ \text { high score } \\ \text { (higher is better) } \\ \text { Sample sive }\end{array} & \begin{array}{c}\text { Predicting HEI-2000 } \\ \text { geod (vs. needs } \\ \text { improvement or poor) }\end{array} \\ \text { NHANES III (1988-1992) } & \text { P-values } & \begin{array}{c}\text { Odds ratios P-values } \\ (95 \% \text { CI) }\end{array}\end{array}$

\begin{tabular}{lccccc}
$\begin{array}{l}\text { Food security status } \\
\begin{array}{l}\text { Food insecurity, } \\
\text { receiving food stamps }\end{array}\end{array}$ & 72 & $-3.33(2.32)$ & 0.15 & $0.36(0.09-1.42)$ & 0.14 \\
\hline $\begin{array}{l}\text { Food insecurity, } \\
\text { no receiving food stamps }\end{array}$ & 107 & $-3.91(1.81)$ & 0.0310 & $0.80(0.27-2.33)$ & 0.67 \\
$\begin{array}{l}\text { Food secure, } \\
\text { no receiving food stamps }\end{array}$ & 4860 & 0.00 (reference) & & 1.00 (reference) & \\
\hline
\end{tabular}

$\begin{array}{lcc} & \begin{array}{c}\text { Predicting HEI-2005 } \\ \text { high score } \\ \text { (higher is better) } \\ \text { Sample size }\end{array} & \begin{array}{c}\text { Predicting HEI-2005 } \\ \text { good (vs. needs } \\ \text { improvement or poor) }\end{array} \\ \text { NHANES III (1988-1992) } & & \begin{array}{c}\text { Pdds ratios P-values } \\ (95 \% \text { CI) }\end{array}\end{array}$

Food security status

\begin{tabular}{lccccc}
$\begin{array}{l}\text { Food insecurity, } \\
\text { receiving food stamps }\end{array}$ & 32 & $-1.22(2.89)$ & 0.67 & $1.35(0.34-5.40)$ & 0.66 \\
\hline $\begin{array}{l}\text { Food insecurity, } \\
\text { no receiving food stamps }\end{array}$ & 180 & $-2.07(1.31)$ & 0.11 & $0.58(0.28-1.19)$ & 0.13 \\
$\begin{array}{l}\text { Food secure, } \\
\text { no receiving food stamps }\end{array}$ & 1828 & 0.00 (reference) & & 1.00 (reference) & \\
\hline
\end{tabular}

SE, standard error; CI, confidence intervals. Odds ratios were adjusted for age, gender, marital status, ethnicity, living arrangements, education, income poverty ratio, medical conditions, ADL, IADL, and body mass index. 
ity. Other demographic or health related factors were independently associated with quality of diet. Food insecure families with older individuals may need to be targeted with new approaches and specifically-designed education and teaching strategies such as popular education; the patient navigator legislation addressing the utilization of native community health workers; and family member caregivers in the area of nutrition and healthy eating specific for these groups. ${ }^{38}$ The revised Food Stamp Program now the SNAP program among other federal nutrition programs for the elder should consider nontraditional and new teaching and education strategies specific to population groups to bring positive changes in elder health status. Due to transitioning sociocultural and economic conditions, ${ }^{23}$ specific population group approaches to health may need to be revised just as in 2006, the USDA Economic Research Service asked the National Academies of Science to revise the term food insecurity. ${ }^{10}$ Finally, communities and populations change from day to day - they are dynamic and not static, hence best process rather than best practices may be most effective; that is, best process meaning self-monitoring by those closest to practice. ${ }^{39}$

\section{References}

1. Organization for Economic Cooperation and Development OECD. Agricultural Policies in OECD Countries: Monitoring and Evaluation, 2009. Available from: http://browse.oecdbookshop.org/oecd/pdfs/ browseit/5109031E.PDF

2. Food and Agricultural Organization. The state of food insecurity in the world, 2003. United Nations: Rome, Italy, 2003. Available from: ftp://ftp.fao.org/docrep/fao/ 006/j0083e/j0083e00.pdf

3. Alaimo K, Briefel RR, Frongillo EA Jr, Olson CM. Food insufficiency exists in the United States: results from the third National Health and Nutrition Examination Survey (NHANES III). Am J Public Health 1998;88:419-26.

4. Lee JS, Frongillo EA Jr. Factors associated with food insecurity among U.S. elderly persons: importance of functional impairments. J Gerontol B Psychol Sci Soc Sci 2001:56:S94-9.

5. Lee JS, Frongillo EA Jr. Nutritional and health consequences are associated with food insecurity among U.S. elderly persons. J Nutr 2001;131:1503-9.

6. Nord M, Andrews M, Carlson S. Household Food Security in the United States, 2008. ERR-83, U.S. Dept. of Agriculture, Econ. Res. Serv. November 2009. Available from: http://www.ers.usda.gov/publications/err83 /err83.pdf

7. Sharkey JR. Nutrition risk screening: The interrelationship of food insecurity, food intake, and unintentional weight change among homebound elders. J Nutr Elder 2004;24, 19-34.

8. Klesges LM, Pahor M, Shorr RI, et al. Financial difficulty in acquiring food among elderly disabled women: results from the women's health and aging study. Am J Public Health 2001;91:68-75.

9. American Dietetic Association. Position of the American Dietetic Association: Food Insecurity in the United States. J Am Dietetic Assoc 2010;110:1368-77.

10. The Food Research and Action Center (FRAC). Hunger and food insecurity in the United States, 2009. Available from: http://www.frac.org/html/hunger_in_the_u s/hunger_index.html

11. Kamp BJ, Wellman NS, Russell C; American Dietetic Association; American Society for Nutrition; Society for Nutrition Education. Position of the American Dietetic Association, American Society for Nutrition, and Society for Nutrition Education: Food and nutrition programs for community-residing older adults. J Am Diet Assoc 2010;110:463-72.

12. Sharkey JR. Risk and presence of food insufficiency are associated with low nutrient intakes and multimorbidity among homebound older women who receive home-delivered meals. J Nutr 2003;133:3485-91.

13. Duerr L. Food security status of older adult home-delivered meals program participants and components of its measurement. J Nutr Elder 2006;26:1-26.

14. Duerr L. Prevalence of food insecurity and comprehensiveness of its measurement for older adult congregate meals program participants. J Nutr Elder 2006;25:121-46.

15. Fuller-Thomson E, Redmond M. Falling through the social safety net: food stamp use and nonuse among older impoverished Americans. Gerontologist 2008;48: 235-44.

16. United States Department of Agriculture (USDA). Supplemental Nutrition Assistance Program eligibility, 2008. Available from: http://www.fns.usda.gov /FSP/applicant_recipients/eligibility.htm

17. Jones SJ, Frongillo EA. The modifying effects of Food Stamp Program participation on the relation between food insecurity and weight change in women. J Nutr 2006;136:1091-4.

18. Poikolainen, Anni. Characteristics of Food Stamp Households: Fiscal Year 2004. Report submitted to the U.S. Department of Agriculture, Food and Nutrition Service. Washington, DC: Mathematica Policy Research; 2005.
19. Dinour LM, Bergen D, Yeh MC. The food insecurity-obesity paradox: a review of the literature and the role food stamps may play. J Am Diet Assoc 2007;107:1952-61.

20. Webb AL, Schiff A, Currivan D, Villamor E. Food Stamp Program participation but not food insecurity is associated with higher adult BMI in Massachusetts residents living in low-income neighbourhoods. Public Health Nutr 2008;11:1248-55.

21. Niedert KC; American Dietetic Association. Position of the American Dietetic Association: Liberalization of the diet prescription improves quality of life for older adults in long-term care. J Am Diet Assoc 2005;105:1955-65.

22. McLaren L. Socioeconomic status and obesity. Epidemiol Rev 2007;29:29-48.

23. Drewnowski A. Obesity and the food environment: dietary energy density and diet costs. Am J Prev Med 2004;27:154-62.

24. Sharkey JR. Longitudinal examination of homebound older adults who experience heightened food insufficiency: effect of diabetes status and implications for service provision. Gerontologist 2005;45:77382.

25. Centers for Disease Control and Prevention. National Health and Nutrition Examination Survey. Questionnaires, datasets and related documentation. http://www.cdc.gov/nchs/nhanes/nhanes_q uestionnaires.htm

26. NHANES III Healthy Eating Index Data File, Series 11, No. 6a, January 2000. ftp://ftp.cdc.gov/pub/Health_Statistics/NCH S/Datasets/NHANES/NHANESIII/6A/heiacc.pdf (

27. McCabe-Sellers BJ, Bowman S, Stuff JE, et al. Assessment of the diet quality of US adults in the Lower Mississippi Delta. Am J Clin Nutr 2007;86:697-706.

28. United States Department of Agriculture. SAS program for the Healthy Eating Index 2005. (HEI2005_NHANES0102.SAS). Available from: http://www.cnpp.usda.gov/ HealthyEatingIndex.htm

29. Guenther PM, Reedy J, Krebs-Smith SM, et al. (). Development and Evaluation of the Healthy Eating Index-2005: Technical Report. Center for Nutrition Policy and Promotion, U.S. Department of Agriculture; 2007. Available from: http://www.cnpp.usda.gov/HealthyEatingIn dex.htm

30. Miller PE, Mitchell DC, Harala PL, et al. Development and evaluation of a method for calculating the Healthy Eating Index2005 using the Nutrition Data System for Research. Public Health Nutr 2011 Feb;14:306-13.

31. Guo X, Warden BA, Paeratakul S, Bray GA. Healthy Eating Index and obesity. Eur J Clin Nutr 2004;58:1580-6. 
32. Bickel G, Nord M, Price C, et al. Guide to Measuring Household Food Security, Revised 2000. U.S. Department of Agriculture, Food and Nutrition Service, Alexandria VA; 2000.

33. Leung CW, Villamor E. Is participation in food and income assistance programmes associated with obesity in California adults? Results from a state-wide survey. Public Health Nutr 2011;14:645-52.

34. Weinstein SJ, Vogt TM, Gerrior SA. Healthy Eating Index scores are associated with blood nutrient concentrations in the third National Health and Nutrition Examination Survey. J Am Diet Assoc 2004;104:576-84.

35. Wirt A, Collins CE. Diet quality--what is it and does it matter? Public Health Nutr 2009;12:2473-92.

36. Radimer KL, Olson CM, Campbell CC. Development of indicators to assess hunger. J Nutr 1990;120:1544-8.

37. Deitchler M, Ballard T, Swindale A, Coates J. Validation of a Measure of Household Hunger for Cross-Cultural Use. Washington, DC: Food and Nutrition
Technical Assistance II Project (FANTA-2), AED, 2010. Available from: http://www.fantaproject.org/downloads/pdfs/HHS_Validat ion_Report_May2010.pdf

38. Balcazar H, Alvarado M, Hollen ML, et al. Salud Para Su Corazon-NCLR: a comprehensive Promotora outreach program to promote heart-healthy behaviors among Hispanics. Health Promot Pract 2006;7:6877.

39. Green LW. From research to "best practices" in other settings and populations. Am J Health Behav 2001;25:165-78. 